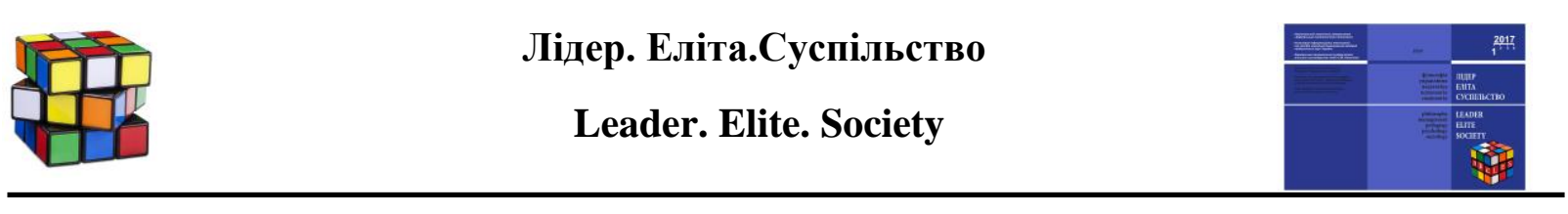

UDK 378.016(430)

doi: 10.20998/2616-3241.2018.1.09

\title{
Valentina Grineva
}

Doctor of Pedagogics, professor, Head of the Primary and Pre-school Education Department, H.S. Skovoroda Kharkiv National Pedagogical University, Kharkiv, Ukraine

ORCID 0000-0002-3027-4622

E-mail:kvn.grineva@gmail.com

\section{Oksana Zhernovnykova}

Doctor of Pedagogics, associate professor, professor of the Department of Mathematics, H.S. Skovoroda Kharkiv National Pedagogical University, Kharkiv, Ukraine

ORCID 0000-0001-5617-6994

E-mail: chornousoxana@i.ua

\section{Oksana Kovalenko}

Doctor of Pedagogics, professor, Head of the Department of English Oral and Written Speech Practice, H.S. Skovoroda Kharkiv National Pedagogical University, Kharkiv, Ukraine

ORCID 0000-0002-3027-4622

E-mail:04.08.1975@hnри.edu.ua

\section{EUROPEAN EXPERIENCE IN TRAINING PROSPECTIVE TEACHERS}

\begin{abstract}
The authors have analysed the experience in training prospective teachers in a number of European countries: the United Kingdom, Germany, France, and Denmark. The standards of training, the requirements to the personality of a modern European teacher, the main principles, methods and forms of training prospective teachers as well as the peculiarities of organising and holding teaching internships have been described. A specific feature of teacher training in the UK is the widespread use of searching method, which is a way of democratization and humanization of pedagogical education. The peculiarity of the bachelor teacher training programs in German universities is that they are multivariate, which makes it possible to get a profession that is not related to teaching at school, and specialised, which means that a teacher is trained for a particular type of school. The main trends in teacher training in Germany are: Europeanization, commitment to international initiatives and projects, student mobility, increased role of research activities, and the wide use of modern multimedia technologies. The peculiarity of the Danish teacher training system is the availability of an additional vocational guidance level which can be acquired at higher public schools. The specific feature of training prospective teachers at the universities of France is a wide choice of long-term and short-term study programs and corresponding diplomas. In addition, teachers, like all French education workers, have the status of civil servants. Universities have a flexible schedule of classes, a variety of modules, full-time or part-time study programs, as well as evening courses, in-house and remote training. On the basis of the conducted analysis, the successful experience in professional training of

(C) Valentina Grineva, Oksana Zhernovnykova, Oksana Kovalenko, 2018
\end{abstract}


prospective teachers abroad has been generalized, and the recommendations for its introduction into the system of higher pedagogical education in Ukraine have been developed.

Key words: training, prospective teacher, higher pedagogical education system, European countries.

\section{Валентина Гриньова}

доктор педагогічних наук, професор, завідувач кафедри початкової, дошкільної та професійної освіти, Харківський національний педагогічний університет імені Г. С. Сковороди, Харків, Україна

E-mail:kvn.grineva@gmail.com

\section{Оксана Жерновникова}

доктор педагогічних наук, доцент, професор кафедри математики, Харківський національний педагогічний університет імені Г. С. Сковороди, Харків, Україна E-mail: chornousoxana@i.ua

\section{Оксана Коваленко}

доктор педагогічних наук, професор, завідувач кафедри практики англійського усного та писемного мовлення, Харківський національний педагогічний університет імені Г. С. Сковороди, Харків, Україна

E-mail:04.08.1975@hnри.edu.ua

\section{СВРОПЕЙСЬКИЙ ДОСВІД ПІДГОТОВКИ МАЙБУТНІХ УЧИТЕЛІВ}

Анотація: Авторами проаналізовано досвід підготовки майбутніх учителів у різних європейських країнах: Великій Британії, Німеччині, Франиії, Данії. Схарактеризовано стандарти підготовки; вимоги до особистості сучасного європейського вчителя; провідні принциии, методи та форми навчання майбутніх учителів; особливості організації та проведення педагогічної практики. Специффічною особливістю підготовки вчителів у Великій Британії є широке застосування технології пошукового навчання, що є способом демократизації та гуманізаиії педагогічної освіти. Особливістю бакалаврської програми підготовки вчителів у німецьких ВНЗ є те, щчо вони багатоваріантні, щуо надає можливість здобути професію, не пов'язану з викладанням у школі, та профільними - зорієнтованим на підготовку вчителя для школи певного типу. Головними тенденціями підготовки вчителів у Німеччині є такі: європеїзація, орієнтація на міжнародні ініціативи та проекти, мобільність студентів, зростання ролі досліднииької діяльності, широке використання сучасних мультимедійних технологій. Особливістю датської системи підготовки вчителів є наявність додаткового профорієнтаиійного рівня, який здобувають у вищих народних школах. Специфіка підготовки майбутніх учителів університетів Франиії зумовлена широким вибором довгострокових $i$ короткострокових програм навчання й отриманням відповідного диплому, до того ж вчителі, як і всі працівники освіти Франції, мають статус державних службовців. Університетам притаманні гнучкий графік занять, розмаїття модулів, навчання з повною або частковою зайнятістю, а також наявність вечірніх курсів, стаціонарної та дистаниійної освіти. На основі проведеного аналізу узагальнено позитивний досвід 
професійної підготовки майбутніх учителів за кордоном, розроблено рекомендаиії щодо його впровадження в систему вищої педагогічної освіти в Украӥні.

Ключові слова:підготовка, майбутній учитель, система вищоїпедагогічноїосвіти, європейські краӥни.

Problem setting. The extension of international relations of Ukraine, the country's acceptance in the world community, joining the Bologna process, and the country's entry into international organizations have raised the social demands for the competences of the teacher as a culture-bearer and a translator of social values, a system of professional, ethical, spiritual, moral and personal qualities, knowledge and skills, which necessitates constant improvement of the teacher's professional training in higher pedagogical educational institutions. The solution of this problem will be effective if the professional training of prospective teachers is organised not only taking into account the best practices of Ukrainian pedagogical education but also introducing successful teacher training experience of other countries.

Recent research and publications analysis. The analysis of psychological and pedagogical literature shows the interest of Ukrainian scholars in the study and implementation of the experience in training prospective teachers accumulated in different countries of the world: in the United Kingdom (J. Atkinson, A. Howatt, T. Kelly, W.Stefens, R. Proterough, N. Avsheniuk, O. Voloshina, T. Garbuza, L. Katrevich, Yu.V. Kishchenko, A. V. Sokolova, N. P. Yatsyshyn, M. Zadorozhna and others), in Germany (T. Wagner, J. Barry,H. Dale, N.Zimpher, K. Howey, N. Makhynia, I.Yankovska, A. Turchin and others), in Poland (S. Derkach, S. Karichkovska, O.Kuchay, L. Shevchuk and others), in France (D. Bucheton, G. Lapostolle, T. Chevaillier, D. Fremy, M. Fremy, O.Golotiuk, V. Lashchikhina and others), in Greece (Y. Korotkova and others), in Denmark (B. Bikvard, P. Laursen, L. Schou, A. Rolyak and others), in Norway (V. Semiletko and others), in the USA (A.Zinovatna, T. Koshmanova, A. Onkovych,
O. Orlovska, L. Cherniy, E. Chuvakova and others), in Japan (O. Ozerska and others).

Paper objective is to analyse the prospects of introducing European teacher training experience to the Ukrainian system of higher pedagogical education.

Paper main body. The traditional teacher training system in Ukraine is not effective, as the educational system is constantly undergoing various reforms, methodological approaches are changing, new rules and principles of education are being developed. Therefore, the introduction of the prospective teachers training system abroad requires analysis and generalization in the context of the standards of such training, the requirements to the personality of a modern teacher, the forms and methods of teaching, organization and conduction of teaching internships.

Training prospective teachers in the United Kingdom. In the UK [11, p. 28; 12 , p. $117 ; 18$, p. $27 ; 22$, p. 48$]$, the requirements to the professional knowledge, skills, abilities, ethics and personal commitment of teachers determine the general professional standards for teachers. Thus, teachers must have such values and moral qualities as justice, openness, impartiality, empathy, perseverance, responsiveness, respect, sincerity, self-awareness. Teachers from the UK are trained in teacher training colleges, according to one-year basic teacher training programs, the Teach First charity program, as well as in SCITT and School Direct schools.

General requirements to the purpose, content and academic results of mastering educational programs, recommendations for the development of curricula and programs are determined by academic standards, though British universities are granted autonomy in their development [21, p. 221].

Note that since 2013 in the United Kingdom, applicants to become teachers have been required to possess basic profes- 
sional skills which are assessed by means of psychological testing and professionally oriented interviews with the admissions committee [19, 2005, p. 36; 25, p. 101].

The theoretical training of teachers in the UK is carried out during undergraduate studies (360 credits, 3-4 years of study), and practical training is organized at PGCE (Postgraduate Certificate in Education) basic teacher training courses. At the University of Birmingham, for example, theoretical training in the first year is followed by the practical and theoretical studies in the second year and then is continued with the self-directed learning and research in the third year. There is a tendency to reduce the share of compulsory subjects and increase the number of elective courses in the curriculum, which allows students to choose disciplines according to their interests and career needs. Practical basic teacher training in the UK consists of the following courses: teaching methods, professional knowledge and school education, teaching internship. Thus, the course of teaching methods is aimed at the development of prospective teachers' professional skills for teaching a certain discipline, since students learn to plan lessons and analyze them. The course of professional knowledge and school education focuses on general school policy and practice, professional and legal duties as well as the responsibility of teachers. As for the teaching internship, it is held in the first, second and third semesters and is interplaced with classes at the university (all together the internship lasts 24 weeks)[9, p. 24].

A specific feature of teacher training in the UK is the widespread use of searching methods, which is a way of democratization and humanization of pedagogical education. The searching method means that the teacher states a complex open problem and students conduct an independent study of this problem using the knowledge acquired by them and identifying those skills and abilities that they lack for solving this problem. Students find facts to justify their ideas, analyze and present them. Searching methods include problem- based learning, field research, case-based learning, individual and group projects, tutor training, students' research, etc.[24, p. 163].

Assessment of students' knowledge is not fundamentally different from that in Ukraine as it is carried out with the help of creative and practical tasks, discourse essays, course papers, project presentations, tests, oral and written examinations. At the same time, the most common form of assessment of British students' academic results is an essay, which provides a comprehensive answer to the question posed by the teacher and needs its critical reflection.

It should be noted that the so-called non-formal education (a form of training which is provided by the general plan of the educational process, but is not regulated by the terms, aims of training or its quality assessment) has acquired great significance in training prospective teachers in Great Britain, as students attend additional training courses on the basis of students educational support centres, are involved in volunteer work in schools, participate in educational events organized by the relevant associations.It is this non-formal education that shapes prospective teachers' need for continuous self-improvement and thus provides the basis for their further professional development [17, p. 72].

Thus, in the UK, a consistent pattern of teacher training is dominant; singlediscipline training is carried out on the basis of an interdisciplinary approach; curricula are clearly coordinated and flexible; preference is given to special subjects. European principles of democratization, humanization of education, justice and equality in society are reflected in the value-based foundations of the National Curriculum and determine the moral aspect of the teachers' professional activities and prospective teachers training system in the UK.

Training prospective teachers in Germany. Teacher training in Germany [23, p. $280 ; 4$, p. $320 ; 26$, p. 124] complies with the uniform standards which define teachers' general pedagogical and subject-specific competences and is based on the National 
Qualifications Framework which contains general requirements to graduates with bachelor's and master's degrees. The teachers' general pedagogical competencies relate to education, assessment and innovation, and the subject-specific competences relate to knowledge and skills in accordance with the specialisation.

Teacher training programs at each university and at each faculty in Germany are developed by Teacher Education Centres. Teacher training programs are modular: the first module of the program includes a number of mandatory courses which are specific for each specialty; the second module includes elective courses that allow to choose, on an alternative basis, one of the compulsory subjects which can be general scientific or applied; the third module includes optional subjects.

Consequently, students' choice of the curriculum content is a characteristic feature of teacher training in Germany.

We also believe that it is very important that bachelor's programs for teacher training at German universities are multivariate, which makes it possible to get a profession that is not related to teaching at school, and specialised, which means that a teacher is trained for a particular type of school. Specialised bachelor programs still dominate multivariate ones, but are gradually replaced with multivariate ones.

A high degree of German universities' autonomy does not make it possible to distinguish a single approach to the introduction of competency-based teacher training. At the same time, the common features of the training of German teachers are as follows: two models of training are applied with different proportions in different states; the training is divided into an academic undergraduate course ending with the First State Examination or obtaining a bachelor's or master's degree, and a pedagogical internship ending in the Second State Examination; regardless of the model, prospective teachers training involves mastering two or three subjects, their teaching methods, pedagogical sciences and school internship; the period of pedagogical internship (Referendariat) runs parallel to seminars where students deepen their theoretical knowledge, practical skills and acquire key competencies; passing the Second State Examination at the end of the pedagogical internship enables students to obtain the status of a civil servant.

In the German educational institutions, an integrative approach to the formation of prospective teachers' competencies prevails. This involves the simultaneous formation of general and special competencies through the use of project, research and other types of problem learning, role-playing games focused on real professional situations[8, p. 247].

Other peculiarities of teacher training in Germany are: together with the internship term, the training lasts 14 semesters (while in Ukraine it is only 10); students become involved into internship since the first semester, and it is longer than in Ukraine; German students go on a pedagogical internship at the place of future employment which lasts for two years. It should be noted that in Germany there is a unified classification of teaching positions which determine the term of prospective teachers training and the ratio of its content.

Training prospective teachers in Denmark. Regarding the system of pedagogical education in Denmark $[6$, p. $613 ; 14$, p. $72 ; 20$, p. 322], the basic training of prospective teachers is carried out at universities (academic education) and in pedagogical colleges (general education). A combination of academic and general education occurs through the unification of common goals and teacher training programs. The system of teacher training in Denmark is characterized by sustained development, a high level of democracy, stability and flexibility, as the personality-oriented, research-based and practice-oriented concepts of pedagogical education play the role of mechanisms that logically combine academic and general substructures into a coherent system [16, p. 136].

Teacher training in Denmark is divided into the basic (or Bachelor) level and the academic level which allows you to obtain a 
Master's degree and Ph.D. It should be noted that the basic level education can be obtained by prospective teachers in colleges and universities, while the academic level is only presented in the classical universities. The peculiarity of the Danish teacher training system is the availability of an additional vocational guidance level which can be acquired at higher public schools.

The content of prospective teachers' training in Denmark is determined by the medium-term (basic) and long-term (academic) types of educational programs. The main principles of the development of educational programs are the following: the principle of the correspondence of the content of teaching education to the requirements of society, science, culture and personality; the unity of theory and practice; humanization; fundamentalism and interdisciplinarity. Bachelor's programs include modules of general cultural, psychological, pedagogical and specialized disciplines, as well as teaching internship. The content of the teaching internship of prospective teachers is structured in accordance with the content of general cultural, psychological, pedagogical and specialized disciplines. This internship is divided into the active and passive phases[3, p.370].

The internship allows the prospective teacher to obtain a Teaching Internship Certificate which is a compulsory supplement to a high school teacher's diploma, and without it the teacher has no right to work in Danish secondary schools. As for master programs they are research- and subject-oriented.

The peculiarity of the content of the prospective teachers training in Denmark, both at the basic and academic levels, is the close relationship, continuity and integration of all studying programs, reorientation from the subject-based to the competence-based approach, the application of the modular principle of structuring the content blocks in accordance with the European Credit Transfer System ECTS. The teacher's professional competencies in Denmark are divided into basic, essential, specialized and value-based. Therefore, all blocks of disciplines in the cur- riculum have a cultural-historical and spiritual content [5, p. 29].

Regarding the forms, methods and techniques of training prospective teachers in Denmark, such training takes place in accordance with the strategy of individual development, applying the techniques of problem, project, interactive, distance learning and using the methods of dialogue and polylogue, discussion, role play, brainstorming which are characterised by humanistic orientation, democracy, orientation on the personal experience of the prospective teacher, development of their creative abilities and critical thinking.

Consequently, training prospective teachers in Denmark is aimed, first of all, at the individual support of students, the formation of their personal goals in studying, their social inclusion, which provides favourable conditions for the comprehensive development of the harmonious personality of the teacher, his freedom, creative abilities, the formation of readiness for self-improvement and self-realization.

Training prospective teachers in France. Pedagogical education in France [7, p. $42 ; 13$, p. $462 ; 10$, p. 326$]$ is aimed at forming a personality, its universal values, therefore all teacher training programs provide for the development of civic qualities of students (the ability to carry out conscious, independent and responsible social activities, the ability to freely express your own views, understand the interlocutor and respect their opinion, the ability to master the valuesemantic principles of being, etc., the formation of their worldview, the fundamentalization of students' knowledge, the development of their creative imagination and so on).

The professional competence of a teacher in France is determined by their basic training, which involves knowledge of the process of cognition; knowledge of general and age psychology, cultural studies, the theory of pedagogy, the national system of education, humanitarian disciplines; communicative and technical skills; availability of professionally important qualities; observance of 
moral and ethical norms of pedagogical activity, etc. [2, p. 92].

In France, there are various forms of undergraduate diplomas: general, technical and vocational ones. Though one can enter the university without obtaining a bachelor's degree by completing the DAEU Exam, which can be of two types: " $A$ " is a humanitarian diploma and " $\mathrm{B}$ " is a diploma in natural sciences or other specialties.

The training of prospective teachers in France is carried out by higher pedagogical schools, universities, as well as teacher training institutes at universities. The specificity of teacher training in higher pedagogical schools is that such training prepares students for fundamental or applied research, teaching in universities and classes for preparation for higher education. To enter the higher pedagogical school you must first complete the two-year class of the corresponding speciality. Studying at school lasts for four years and gives you the opportunity to get a certificate that gives you the right to teach. Passing an additional exam, "aggregation", contributes to raising the teacher's salary and insures career advancement. It should be noted that graduates of higher pedagogical schools will have for at least 10 years to work in the public sector of education.

Teachers, like all French education workers, have the status of civil servants. The specific nature of training prospective teachers at the universities of France is a wide choice of long-term and short-term study programs and corresponding diplomas. Universities have a flexible schedule of classes, a variety of modules, full-time or part-time study programs, as well as evening courses, in-house and remote training [1, p. 5].

As for teacher training institutes at universities, they train teachers for preschool institutions, primary and secondary schools, senior lyceum classes, professional lyceums, etc. In such institutions, deputy directors of extracurricular activities, teachers for mentally retarded children and children with disabilities are also trained.

The peculiarities of prospective teacher training in France are: its relevance to historical, political and social contexts; cultural and national traditions, views on the teacher, their status, role, competence and professional functions.

The guiding principle of the organization of the educational process is the principle of interaction between theory and practice. In addition, the training of prospective teachers in France involves creating a comfortable environment in the class, enjoying the classes, explaining the material in an interesting and motivating way, continuous monitoring and ensuring understanding of the educational material, helping students, developing their self-esteem[15, p. 122]. Training sessions are also aimed at the disclosure by prospective teachers' personal talents and skills, the formation of harmonious relationships with their students.

Conclusions of the research. The analysis of the experience in training prospective teachers makes it possible to make suggestions on its use to improve the system of pedagogical education in Ukraine, namely: to introduce professional selection of entrants to teaching professions; to use the potential of non-formal education; to increase the duration of teaching internships and to introduce a system of mentoring; to involve experienced teachers-innovators in the development of the content of educational and professional training programs for teachers; to include teaching subjects providing for inclusive education; to give preference to active learning methods based on interdisciplinary and problem-based approaches; to create conditions for the exchange of experience of higher pedagogical educational institutions with foreign educational institutions; bring the system of training prospective teachers in Ukraine into conformity European standards in order to make it possible to recognize domestic diplomas or obtain double diplomas. 


\section{References}

1. Anoshkova, T. A. (2015). Implementation of global competency in higher education. Advanced Education, 3, 48. http://dx.doi.org/10.20535/2410-8286. 43743 [in English].

2. Arnet-Clark, I., Smeets-Cowan, R. \& Kühnis, J. (2015). Competences in Teacher Education at Schwyz University of Teacher Education (HHSZ), and the Swiss Education Policy. Pädagogische Hochschule Schwyz, 88-100. Retrievedfromhttp://www. phsz.ch[in English].

3. Barrick, M. R., Mount, M. K. Yes, personality matters: moving on to more important matters. Hum. Perform. 2005.18.359372. https://doi.org/10.1207/s15327043hup 1804_3 [in English].

4. Barry, J., Dale, H. (2003). Educational Psychology: A Century of Contributions, Lawrence Erlbaum Associate. Mahwah[in English].

5. Bhola, H.S. \& Gómez, S.V. (2008). Signposts to literacy for sustainable development: complementary studies. Hamburg, Germany: UNESCO Institute for Lifelong Learning [in German].

6. Bikvard, B. (1997). Teacher Professional Development in Denmark. Phi Delta Kappan. 78(8), 611-614 [in English].

7. Bucheton, D. (1996) Interactions: dialoguer, communiquer. Le Francais aujourd'hui: mars,113, 11-109[in English].

8. Chamorro-Premuzic, T., Furnahm, A., Martin, L. Personality and approaches to learning predict preference for different teaching methods. Learn. Individ. Differ. 2007. 17. 241-250. https://doi.org/ 10.1016/j.lindif.2006.12.001[in English].

9. Cheng, E.W.A review of transfer of training studies in the past decade. Pers. Rev. 2001. $30 . \quad$ https://doi.org/102 118.10.1108/00483480110380163[in English].

10. Fremy, D., Fremy, M. (2005). Tout sur tout, tout de suite. Paris: Laffont, 219.
11. Howatt, A. P. (1994). A History of English Language Teaching. Oxford University Press [in French].

12. Kelly, T. A. (1992). History of Adult Education in Great Britain. From the Middle ages to the twentieth century. Liverpool University Press[in English].

13. Lapostolle, G., \& Chevaillier, T. (2008), Between Necessity and Constraints: The Reform of Teacher Training in France (1990-2007). Higher Education in Europe, 457-470 [in English].

14. Laursen, P. F. (2006). Educating the Authentic Teacher. Lindgren, Ulla: A Nordic Perspective on Teacher Education in a time of Societal Change: contributions from a Nordic conference that focused on the professional teacher role. Umea University Publ, 65-76 [in English].

15. Major, D. A., Turner, J. E., Fletch er, T. D. Linking proactive personality and the big five to motivation to learn and development activity. J. Appl. Psychol. 2006.91.https://doi.org/927-935.10.1037/00 21-9010.91.4.927 [in English].

16. Mikulecky, L. (1982). Job literacy: the relationship between school preparation and workplace actuality. Reading Research Quarterly, 17 (3), 400-419. https://doi.org/10.2307/747527[in English].

17. Mulder, M., Weigel, T. \& Collins, K. (2007). The concept of competence in the development of vocational education and training in selected EU member states: a critical analysis. Jornal of Vocational Education \& Training, 1, 67-88. https://doi.org/10.1080/13636820601145630[ in English].

18. Proterough, R., Atkinson, J. (1991). The making of English Teachers. Open University Press[in English].

19. Recommendation of the European parliament and of the council on key competences for lifelong learning (2005). Commission of the European communities, Brussels.

Retrievedfromhttp://jows.pl/sites/default/files 
/KE_European\%20Indicator\%20of\%20Lang uage\%20Competence_2005.pdf[in English].

20. Schou, L. R. (2001). Democracy in Education. Studies in Philosophy and Education. 20, 317-329 [in English].

21. Shpytalevsjka, Gh.

Kharakterystyka kljuchovykh

predmetnykh kompetentnostej

(2011). kompetencicj osobystosti [Description Of Key Competences And Subject Competence And Personality].Problemy pidghotovky suchasnogho vchytelja, 4 (2), 220-225 [in Ukrainian].

22. Stefens, W. B. (1987). Education, Literacy and Society, 1830-70. The geography of diversity in provincial England. Manchester University Press[in English].

23. Wagner, T. (2015). Most Likely to Succeed: Preparing Our Kids for the Innovation Era Hardcover. Scribner[in English].

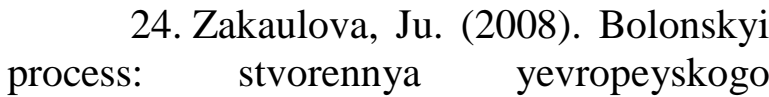

Стаття надійшла до редколегії: 15.05.2018 osvitnyogo prostoru [The Bolonian process: creation of European educational space]. Visnyk Kharkivskogo natsionalnogo universytetu imeni V.N. Karazina, 55, 161165 [inUkrainian].

25. Zhernovnykova O. A. (2014). Spetsyfika dydaktychnoi pidhotovky studentiv-matematykiv pedahohichnykh VNZ do roboty u koledzhakh ta profesiinykh litseiakh [Specificity of didactic preparation of students-mathematicians of pedagogical universities for work in colleges and professional lyceums]. Pedagogy and psychology. Kharkiv: TOV «Shchedrasadyba plius», 45, 97-105 [inUkrainian].

26. Zimpher, N., Howey, K. (1992). Policy and practice toward the improvement of teacher education. A report prepared for the North Central Regional Educational Laboratory (NCREL) [in English]. 